\title{
Early detection of Angelman syndrome resulting from de novo paternal isodisomic 15q UPD and review of comparable cases
}

\author{
Emese Horváth ${ }^{1 *}$, Zsuzsanna Horváth ${ }^{1}$, Dóra Isaszegi ${ }^{1}$, Gyurgyinka Gergev², Nikoletta Nagy 1,3, János Szabó ${ }^{1}$, \\ László Sztriha², Márta Széll ${ }^{1,3}$ and Emőke Endreffy ${ }^{2}$
}

\begin{abstract}
Background: Angelman syndrome is a rare neurogenetic disorder that results in intellectual and developmental disturbances, seizures, jerky movements and frequent smiling. Angelman syndrome is caused by two genetic disturbances: either genes on the maternally inherited chromosome 15 are deleted or inactivated or two paternal copies of the corresponding genes are inherited (paternal uniparental disomy). A 16-month-old child was referred with minor facial anomalies, neurodevelopmental delay and speech impairment. The clinical symptoms suggested angelman syndrome. The aim of our study was to elucidate the genetic background of this case.

Results: This study reports the earliest diagnosed angelman syndrome in a 16-month-old Hungarian child. Cytogenetic results suggested a de novo Robertsonian-like translocation involving both q arms of chromosome 15: 45,XY, der(15;15)(q10;q10). Molecular genetic studies with polymorphic short tandem repeat markers of the fibrillin-1 gene, located in the 15q21.1, revealed that both arms of the translocated chromosome were derived from a single paternal chromosome 15 (isodisomy) and led to the diagnosis of angelman syndrome caused by paternal uniparental disomy.

Conclusions: AS resulting from paternal uniparental disomy caused by de novo balanced translocation t $(15 \mathrm{q} ; 15 \mathrm{q})$ of a single paternal chromosome has been reported by other groups. This paper reviews 19 previously published comparable cases of the literature. Our paper contributes to the deeper understanding of the phenotype-genotype correlation in angelman syndrome for non-deletion subclasses and suggests that patients with uniparental disomy have milder symptoms and higher BMI than the ones with other underlying genetic abnormalities.
\end{abstract}

Keywords: Angelman syndrome, Isodisomic 15, Uniparental disomy, Balanced translocation chromosome 15q

\section{Background}

Angelman syndrome (AS; OMIM 105830) is a rare neurodevelopmental disorder characterized by severe mental and physical delay, limited speech, fine tremor, ataxia, excessive mouthing behavior, fascination with water, jerky limb movements, seizures, craniofacial abnormalities and unusually happy sociable behavior characterized by frequent episodes of inappropriate smiling [1,2].

Seventy percent of AS cases investigated with molecular genetics methods are the result of a small deletion in the

\footnotetext{
* Correspondence: horvath.emese@med.u-szeged.hu

${ }^{1}$ Department of Medical Genetics, University of Szeged, 4 Somogyi B. utca,

H-6720, Szeged, Hungary

Full list of author information is available at the end of the article
}

11-13 region of the maternal chromosome 15. A deletion in the same region of the paternal chromosome 15 results in the sister disorder Prader-Willi syndrome (PWS). Expression of the genes in the 11-13 region is regulated by the PWS/AS imprinting center (IC), which differentially silences the paternal copy of the ubiquitin protein ligaseE3A $(U B E 3 A)$ gene in the hippocampus and in the cerebellum. Other genetic abnormalities resulting in AS reported include uniparental disomy (UPD; 5\%), mutations of the IC (5\%), mutations of the UBE3A gene (10\%), and other mechanisms (10\%) $[3,4]$.

In this paper, we report a 16-month-old Hungarian child, who was referred to our genetic counseling unit with delayed psychomotor and speech development and

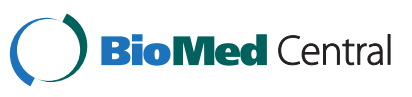


dysmorphic features, including wide nasal bridge, low set ears, thick lips, wide mouth with protuberant tongue (Figure 1). Tongue thrusts were observed. Head circumference was $47 \mathrm{~cm}$ (25 percentile). The affected child was born at term after an uneventful first pregnancy with normal weight (3260 g) and head circumference $(33 \mathrm{~cm})$. The Apgar scores were 9, 10 and 10 at 1, 5 and 10 minutes, respectively. No signs of decreased fetal movement, neonatal hypotonia or feeding difficulties were reported. The clinical phenotype of the patient suggested AS, therefore molecular cytogenetic investigations were carried out to elucidate the genetic background of the presented case.

\section{Results}

Cytogenetic analysis demonstrated a 45,XY,der(15;15) (q10;q10) karyotype in all analyzed cells from the index patient (III/1, Figure 2). All metaphase cells displayed 45 chromosomes, suggesting a balanced homologous rearrangement of the long arms of chromosomes 15 . The parent's karyotype was found to be normal, indicating a de novo chromosome rearrangement in the patient.

Analysis of polymorphic short tandem repeat (STR) markers of the fibrillin-1 gene, which is located in $15 \mathrm{q} 21.1$, revealed that both long arms of the aberrant chromosome 15 were inherited from the father (Figure 3), allowing a diagnosis of AS caused by paternal UPD. The patient was homozygous at all loci for which his father was heterozygous, indicating that the rearrangement resulted from an isodisomic 15q.

\section{Discussion}

Cytological and molecular genetic investigation revealed UPD suggesting a Robertsonian-like translocation 45,XY, $\operatorname{der}(15 ; 15)(\mathrm{q} 10 ; \mathrm{q} 10)$, a rearrangement of the acrocentric

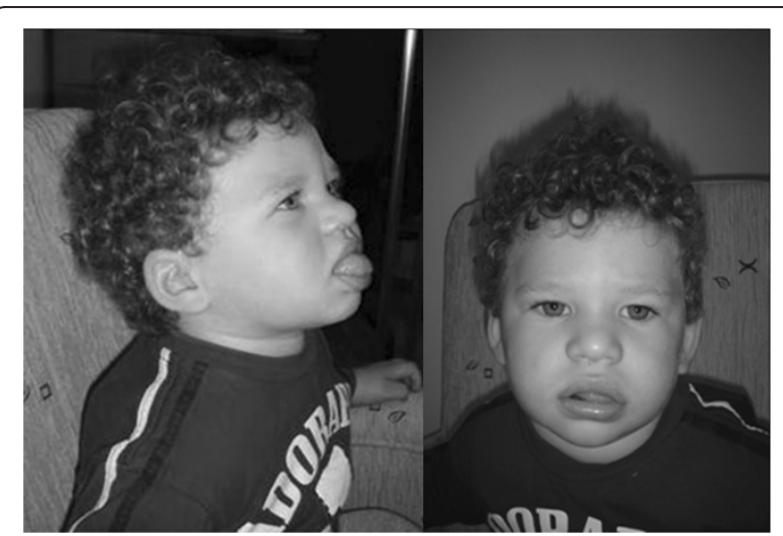

Figure 1 Clinical features of a patient with Angelman syndrome resulting from de novo paternal isochromosome 15q UPD. The dysmorphic symptoms of the 16 month old child include wide nasal bridge, low set ears, thick lips, wide mouth and protruding tongue. chromosomes. Robertsonian translocations mostly form de novo due to intrinsic properties of the acrocentric chromosomes, which are likely to be the results of the high homology between the short arm DNA sequences of them [5]. A similar balanced 15;15 translocation resulting from paternal UPD in AS were reported by Freeman et al. (1993) [6], by Tonk et al. (1996) [7], by Ramsden et al. (1996) [8], by Guitart et al. (1997) [9], by Fridman et al. (1998) [10] and by Robinson et al. (2000) [11].

Results from polymorphic STR marker analysis for the fibrillin-1 gene, located in 15q21.1, indicated that both arms of the aberrant chromosome 15 were inherited from the father, allowing a diagnosis of AS caused by paternal UPD. DNA polymorphic markers demonstrated that the patient was homozygous at all loci for which the father was heterozygous, suggesting that the structural rearrangement was an isodisomic $15 \mathrm{q}$ and not a Robertsonian translocation. Similar cases of AS resulting from isodisomic $15 \mathrm{q}$ associated UPD have already been demonstrated by Freeman et al. (1993) [6] and by Robinson et al. (2000) [11], however, the majority of the previously reported paternal UPD associated AS cases were heterodisomic [7-10].

The severity of AS symptoms varies significantly. Bottani et al. (1994) were the first, who reported that the phenotype of AS with paternal isochromosome 15 is milder than those caused by other mechanisms [12]. This observation was confirmed by Tonk et al. (1996) [7], Smith et al. (1997) [13], Fridman et al. (1998) [10] and Moncla et al. (1999) [14], however Prassad et al. (1997) [15] have not observed differences between deletion and UPD, moreover Poyatos et al. (2002) described an even more severe phenotype [3]. The mildest symptoms have been reported for mutations of the UBE3A gene $[2,12,14,16]$, whereas the most severe symptoms are reported for large deletions on chromosome 15 $[2,14,16]$. Varela et al. (2004) suggested that AS patients with UPD may remain undiagnosed because of their milder or less typical phenotype, leading to an overall under-diagnosis of the disease (Table 1) [17,18]. According to Tan et al. (2011) [4], 46\% of AS children with UPD/imprinting defect showed significantly higher body mass index (BMI) than the ones carrying deletions.

In the investigated patient, we observed dysmorphic features, developmental delay, speech impairment and sleep disturbances, excessive mouthing behavior, short attention span, hand flapping, fascinating with water, and characteristic EEG and MRI results. The clinical features of our patient are similar to previously published results $[4,7,9,12]$. The patient's AS symptoms are relatively mild, which correlates well with the previous observations that AS patients with UPD usually have less severe clinical symptoms $[8,10,11,13]$. The BMI of our patients was $>85 \%$, which correlated well with the previous results of Tan et al. 

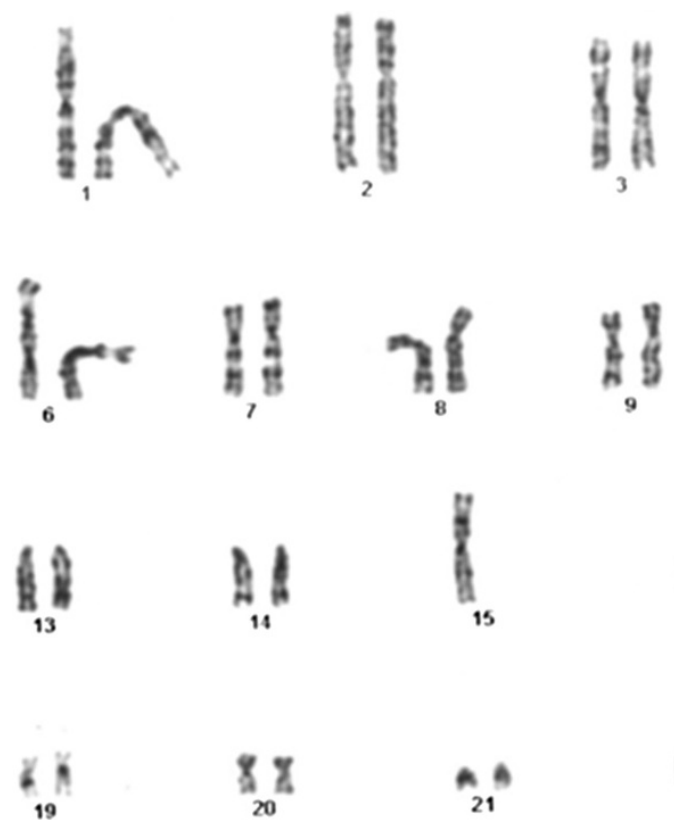
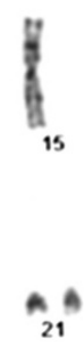

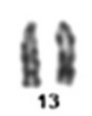

20
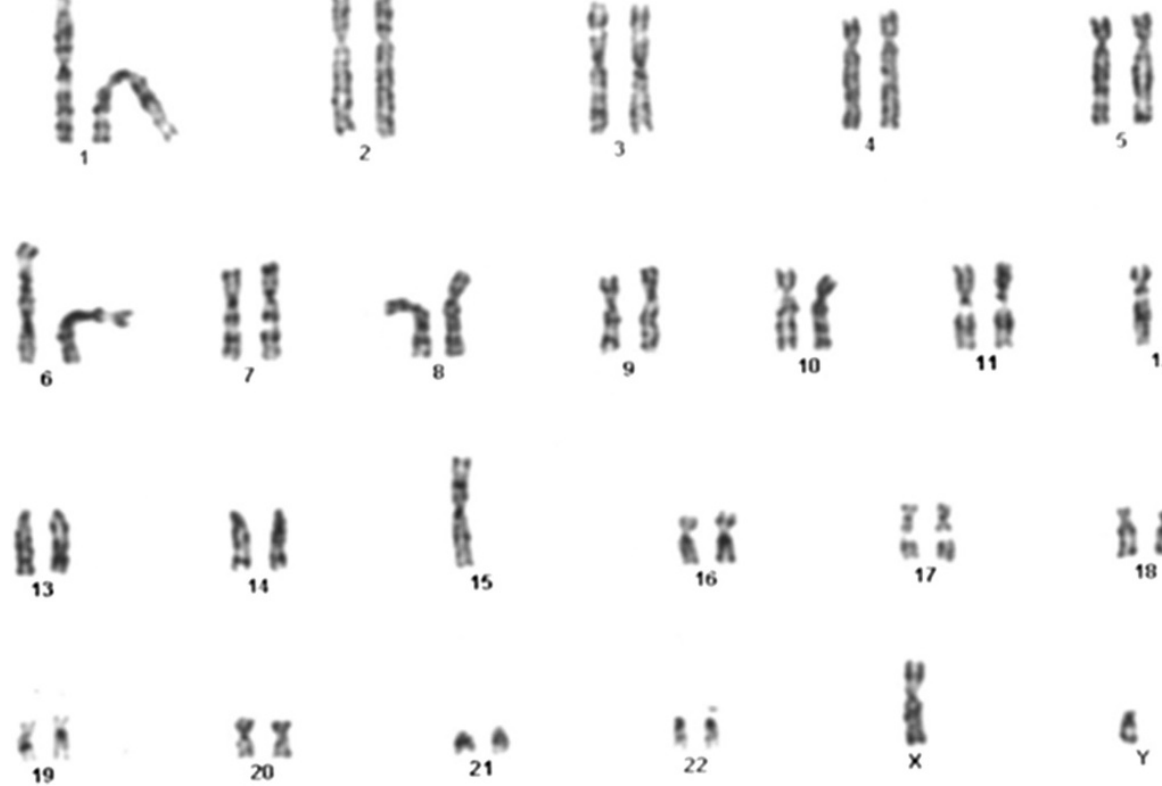
homologous rearrangement between the long arms of chromosomes 15. Cytogenetic result: 45,XY der(15;15)(q10;q10).

I.

$\sum_{\substack{3 \\ n}}^{2}$ $\frac{1}{22}$
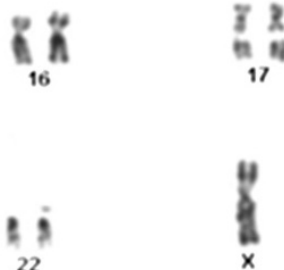

18

$c_{Y}$

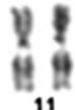

$\frac{2}{4}$

12

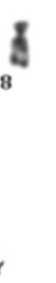

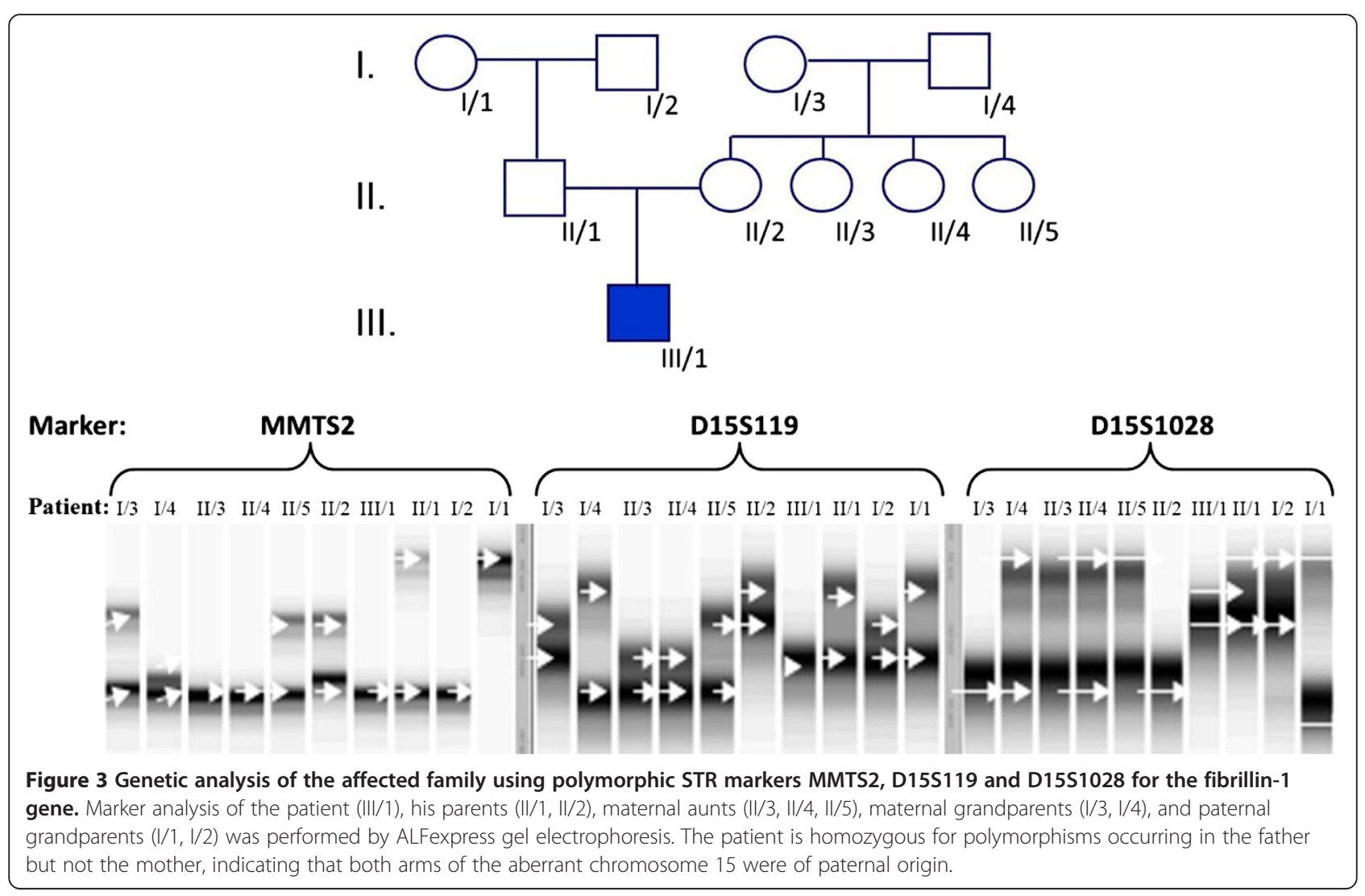


Table 1 The clinical features of the patient, in order of frequency, compared to the 13 AS patients with UPD/ imprinting defects reported by Tan [4]

\begin{tabular}{ccc}
\hline $\begin{array}{c}\text { The analyzed } \\
\text { parameters at } \\
\text { diagnosis }\end{array}$ & $\begin{array}{c}\text { Values for the } \\
\text { patient described in } \\
\text { this report }\end{array}$ & $\begin{array}{c}\text { Values for the 13 AS } \\
\text { patients with UPD/ } \\
\text { imprinting defects } \\
\text { reported by Tan [4] }\end{array}$
\end{tabular}

Age (months) at

diagnosis

\begin{tabular}{|c|c|c|}
\hline $0-24$ & 1 & 0 \\
\hline $25-36$ & - & 5 \\
\hline $37-60$ & - & 8 \\
\hline Gender & $M$ & $8 M / 5 F$ \\
\hline $\begin{array}{l}\text { Short attention } \\
\text { span }\end{array}$ & + & $12 / 13(92 \%)$ \\
\hline $\begin{array}{l}\text { History of sleep } \\
\text { difficulties }\end{array}$ & + & $12 / 13(92 \%)$ \\
\hline $\begin{array}{c}\text { Normal tone at } \\
\text { evaluation }\end{array}$ & + & $12 / 13(92 \%)$ \\
\hline $\begin{array}{l}\text { Mouthing } \\
\text { behavior }\end{array}$ & + & $11 / 13(85 \%)$ \\
\hline Hand flapping & + & $11 / 13(85 \%)$ \\
\hline Drooling & + & 10/13 (77\%) \\
\hline $\begin{array}{c}\text { Feeding } \\
\text { difficulties in } \\
\text { infancy }\end{array}$ & - & 10/13 (77\%) \\
\hline $\begin{array}{l}\text { Ataxic or broad } \\
\text { based gait }\end{array}$ & - & $8 / 11(73 \%)$ \\
\hline $\begin{array}{l}\text { Gastro-esophageal } \\
\text { reflux }\end{array}$ & - & $9 / 13(69 \%)$ \\
\hline $\begin{array}{c}\text { Widely spaced } \\
\text { teeth }\end{array}$ & + & $9 / 13(69 \%)$ \\
\hline $\begin{array}{c}\text { Fascination with } \\
\text { water }\end{array}$ & + & $8 / 13(62 \%)$ \\
\hline $\begin{array}{c}\text { Easily provoked } \\
\text { laughter }\end{array}$ & + & $8 / 13(62 \%)$ \\
\hline Clinical seizures & - & $6 / 13(46 \%)$ \\
\hline $\mathrm{BMI}>85 \%$ & + & $6 / 13(46 \%)$ \\
\hline $\begin{array}{l}\text { Unusually light } \\
\text { hair or skin color }\end{array}$ & - & $3 / 13(23 \%)$ \\
\hline Prognathism & - & $3 / 13(23 \%)$ \\
\hline $\begin{array}{c}\text { Mid-face } \\
\text { hypoplasia }\end{array}$ & - & $2 / 13(15 \%)$ \\
\hline
\end{tabular}

(2011) [4] and further confirmed that AS patients with UPD have significantly higher BMI than AS patients with other underlying genetic abnormalities.

The patient was diagnosed with AS at the age of 16 months, earlier than in previous reports of UPD, allowing the parents to be given a correct prognosis and an explanation of delayed neurological developmental as well as the possibility of early interventional therapy. In addition, the parents were counseled that the child is at risk for obesity and its associated complications, which could be managed with lifestyle adjustments. As the aberration was the result of a de novo occurrence, the parents were not counseled on the risk of recurrence for further pregnancies.

\section{Conclusions}

In this paper we report the case of a 16-month-old Hungarian boy affected by AS due to UPD. The early diagnosis of AS has great significance, it allows the parents to be given a correct prognosis and the possibility of early interventional therapy. The detection of UPD and reviewing the previous cases reported in the literature have also pivotal role, since it contributes to the deeper understanding of the phenotype-genotype correlation in AS for non-deletion subclasses. Our data suggest that AS patients with UPD have milder symptoms and higher BMI than AS patients with other underlying genetic abnormalities.

\section{Methods}

Cytogenetic analysis of the child and his parents was carried out with standard methods using $\mathrm{G}$ banding with the Cytovision imaging system. The results of the cytogenetic studies suggested UPD, and, therefore, further molecular genetic studies were carried out. Genomic DNA was extracted from venous blood of the index patient (III/1), his parents (II/1, II/2), his grandparents $(\mathrm{I} / 1, \mathrm{I} / 2, \mathrm{I} / 3, \mathrm{I} / 4)$ and his maternal aunts (II/3, II/4, II/5) [19]. Chromosome 15 segregation analysis with intragenic and extragenic markers for the fibrillin-1 gene was performed for all family members using amplified fragment length polymorphism analysis on an ALFexpress instrument [20]. To determine the molecular background and the recurrence risk, primers for the following microsatellite markers were used in the analysis: D15S119, D15S1028 and MMTS2.

\section{Consent}

Written informed consent was obtained from the patient's legal guardian for publication of this case report and accompanying images. A copy of the written consent is available for review by the Editor-in-Chief of this journal.

\section{Abbreviations}

AS: Angelman syndrome; PWS: Prader-Willi syndrome; IC: Imprinting center; UBE3A: Ubiquitin protein ligaseE3A gene; UPD: Uniparental disomy;

STR: Short tandem repeat; BMI: Body mass index.

Competing interests

The authors declare that they have no competing interest.

\section{Authors' contribution}

$\mathrm{EH}$ contributed to data collection and the first draft of the manuscript. $\mathrm{ZH}, \mathrm{DI}$ and NN carried out the mutation analysis. GG and JS cared for the patient. LS, MS and EE were mentors who contributed equally to this work. All authors read and approved the final manuscript. 


\section{Acknowledgments}

TÁMOP-4.2.2.A-11/1/KONV-2012-0035 grant, TÁMOP-4.2.2/B-10/1/KONV-20100012 grant. Dr. László Sztriha received funds from the Marie Curie International Reintegration Grant (MIRG-CT-2005-030967) within the 6th European Community Framework Program. OTKA PD104782 2012-2015 grant, Nikoletta Nagy is supported by Janos Bolyai Scholarship 2011-2014.

\section{Author details}

'Department of Medical Genetics, University of Szeged, 4 Somogyi B. utca, H-6720, Szeged, Hungary. 'Department of Pediatrics and Child Health Centre, University of Szeged, Szeged, Hungary. ${ }^{3}$ Dermatological Research Group of the Hungarian Academy of Sciences, University of Szeged, Szeged, Hungary.

Received: 9 July 2013 Accepted: 10 August 2013

Published: 8 September 2013

\section{References}

1. Clayton-Smith J, Laan L: Angelman syndrome: a review of the clinical and genetic aspects. J Med Genet 2003, 40:87-95.

2. Williams CA, Beaudet AL, Clayton-Smith J, Knoll JH, Kyllerman M, Laan LA, Magenis RE, Moncla A, Schinzel AA, Summers JA, Wagstaff J: Angelman syndrome 2005: updated consensus for diagnostic criteria. Am J Med Genet 2006, 140:413-418.

3. Poyatos D, Guitart M, Gabau E, Brun C, Mila M, Vaquerizo J, MD C: Severe phenotype in Angelman syndrome resulting from paternal isochromosome 15. J Med Genet 2002, 39:4.

4. Tan WH, Bacino CA, Skinner SA, Anselm I, Barbieri-Welge R, Bauer-Carlin A, Beaudet AL, Bichell TJ, Gentile JK, Glaze DG, Horowitz LT, Kothare SV, Lee HS, Nespeca MP, Peters SU, Sahoo T, Sarco D, Waisbren SE, Bird LM: Angelman syndrome: mutations influence features in early childhood. Am J Med Genet 2011, 155:81-90.

5. Kim SR, Shaffer LG: Robertsonian translocations: mechanisms of formation, aneuploidy, and uniparental disomy and diagnostic considerations. Genet Test 2002, 6:163-168.

6. Freeman SB, May KM, Pettay D, Fernhoff PM, Hassold TJ: Paternal uniparentaldisomy in a child with a balanced 15;15 translocation and Angelman syndrome. Am J Med Genet 1993, 45:625-630

7. Tonk V, Schultz RA, Christian SL, Kubota T, Ledbetter DH, Wilson GN: Robertsonian $(15 q, 15 q)$ translocation in a child with Angelman syndrome: evidence of uniparentaldisomy. Am J Med Genet 1996, 66:426-428.

8. Ramsden S, Gaunt L, Seres-Santamaria A, Clayton-Smith J: A case of Angelman syndrome arising as a result of a de novo Robertsonian translocation. Acta Genet Med Gemellol 1996, 45:255-261

9. Guitart M, Escudero T, Gabau E, Dorminguez MC, Jimenez MD, Mila M, Coll MD: Two new cases of Angelman syndrome with a balanced 15;15 translocation and paternal uniparental disomy. Cytogenet Cell Genet 1997, 77:227.

10. Fridman C, Varela MC, Nicholls RD, Koiffmann CP: Unusual clinical features in an Angelman syndrome patient with uniparental disomy due to a translocation 15q15q. Clin Genet 1998, 54:303-308.

11. Robinson WP, Christian SL, Kuchinka BD, Peñaherrera MS, Das S, Schuffenhauer S, Malcolm S, Schinzel AA, Hassold TJ, Ledbetter DH: Somatic segregation errors predominantly contribute to the gain or loss of a paternal chromosome leading to uniparental disomy for chromosome 15. Clin Genet 2000, 57:349-358.

12. Bottani $A$, Robinson WP, DeLozier-Blanchet CD, Engel E, Morris MA, Schmitt B, Thun-Hohenstein L, Schinzel A: Angelman syndrome due to paternal uniparentaldisomy of chromosome 15: milder phenotype? Am J Med Genet 1994, 51:35-40.

13. Smith A, Marks R, Haan E, Dixon J, Trent RJ: Clinical features in 4 patients with Angelman syndrome resulting from paternal uniparental disomy. J Med Genet 1997, 34:426-429.

14. Moncla A, Malzac P, Voelckel MA, Auquier P, Girardot L, Mattei MG, Philip N, Mattei JF, Lalande M, Livet MO: Phenotype-genotype correlation in 20 deletion and non-deletion Angelman syndrome patients. Eur J Hum Genet 1999, 7:131-139

15. Prasad C, Wagstaff J: Genotype and phenotype in Angelman syndrome caused by paternal UPD 15. Am J Med Genet 1997, 70:328-329.

16. Liehr T: Cases with uniparental disomy. http://www.fish.uniklinikum-jena.de/ UPD.html. [accessed 05/08/2013].

17. Lossie AC, Whitney MM, Amidon D: Distinct phenotypes distinguish the molecular classes of Angelman syndrome. J Med Genet 2001, 38:834-845.
18. Varela MC, Kok F, Otto PA, Koiffmann CP: Phenotypic variability in Angelman syndrome: comparison among different deletion classes and between deletion and UPD subjects. Eur J Hum Genet 2004, 12:987-992.

19. Abrams DJ, Aronoff AR, Ann Berend S, Roa BB, Shaffer LG, Geier MR: Prenatal diagnosis of a homologous Robertsonian translocation involving chromosome 15. Prenat Diagn 2011, 21:676-679.

20. Judge DP, Biery NJ, Dietz HC: Characterization of microsatellite markers flanking FBN1: utility in the diagnostic evaluation for Marfan syndrome. Am J Med Genet 2001, 99:39-47.

doi:10.1186/1755-8166-6-35

Cite this article as: Horváth et al:: Early detection of Angelman syndrome resulting from de novo paternal isodisomic 15q UPD and review of comparable cases. Molecular Cytogenetics 2013 6:35.

\section{Submit your next manuscript to BioMed Central and take full advantage of:}

- Convenient online submission

- Thorough peer review

- No space constraints or color figure charges

- Immediate publication on acceptance

- Inclusion in PubMed, CAS, Scopus and Google Scholar

- Research which is freely available for redistribution 